\title{
MANDATY I GRZYWNY W POLSKICH GMINACH - NARZĘDZIE POLITYKI KARNEJ CZY POLITYKI BUDŻETOWEJ?*
}

\section{WSTĘP}

W ostatnich latach tematyka mandatów i grzywien nakładanych przez polskie samorządy terytorialne była szeroko obecna w polskiej debacie publicznej. Kontrowersje wywoływało wyjątkowo częste stosowanie przez straż miejską fotoradarów w niektórych gminach oraz stosunkowo duży udział dochodów z mandatów i grzywien w budżetach tych gmin. Pojawiło się wiele akcji społecznego sprzeciwu, a w niektórych gminach w Polsce odbyły się referenda lokalne dotyczące likwidacji straży miejskich. W 2013 r. policja odnotowała 101 przypadków zniszczenia lub uszkodzenia fotoradarów. Najwyższa Izba Kontroli w tym samym roku oceniła działalność części jednostek samorządu terytorialnego w zakresie nakładania mandatów jako zgodną z prawem, lecz nierzetelną i niemająca wpływu na bezpieczeństwo ruchu publicznego oraz bezpieczeństwo ruchu drogowego ${ }^{1}$.

Wszystkie kontrowersje na temat dochodów samorządów terytorialnych z mandatów czynią zasadną pogłębioną analizę tego zjawiska oraz stanowią motywację do przeprowadzenia badania. Mandaty i grzywny z zasady maja stanowić środek polityki karnej państwa, której celem jest poprawa bezpieczeństwa publicznego. Moga one być jednak wykorzystywane jako sposób osiagania dodatkowych dochodów niepodatkowych, natomiast wartość i częstotliwość ich wystawiania może wpływać na poparcie dla polityków rządzących danym samorządem terytorialnym. Celem tego artykułu jest dokonanie pogłębionej analizy dochodów z mandatów i grzywien w polskich gminach, a następnie weryfikacja hipotez o istotności rzeczywistych czynników wpływajacych na ich wysokość. Czynniki te podzielono na trzy grupy związane z polityką karna państwa, polityką fiskalna gminy oraz lokalnym politycznym cyklem koniunkturalnym. Weryfikacji poddano hipotezy o wpływie poziomu

\footnotetext{
* Poglądy wyrażone w tym artykule są prywatnymi poglądami autora i niekoniecznie oddają stanowisko instytucji, w których autor jest zatrudniony.

${ }^{1}$ Najwyższa Izba Kontroli (2013).
} 
przestępczości i zmiennych fiskalnych na wysokość dochodów z mandatów w polskich gminach oraz o istnieniu lokalnego politycznego cyklu koniunkturalnego w tej kategorii dochodów.

W pierwszej części artykułu zawarto przegląd literatury przedmiotu i dotychczasowych badań w tej dziedzinie, w drugiej - zaprezentowano dane statystyczne na temat dochodów z mandatów w polskich samorządach terytorialnych w skali całego kraju i poszczególnych gmin. Zidentyfikowano gminy cechujace się znacznie wyższymi średnimi dochodami z mandatów od ogólnopolskiej średniej oraz ukazano mapę przedstawiającą ich geograficzne rozmieszczenie. W części trzeciej zaprezentowano model ekonometryczny, którego estymacja pozwala na ocenę rzeczywistych determinant dochodów z mandatów w poszczególnych gminach. Wyniki estymacji przedstawiono w części czwartej, a całość zamyka podsumowanie.

\section{PRZEGLĄD LITERATURY}

Tematyka mandatów i grzywien nakładanych przez samorządy stosunkowo rzadko jest przedmiotem badań naukowych, a literatura przedmiotu pozostaje uboga. Dotyczy to zarówno Polski, jak i krajów Zachodu. Istniejąca luka badawcza stanowi kolejny czynnik motywujacy do przeprowadzenia odpowiedniej analizy. Pomimo tego powstało kilka opracowań na temat wykorzystania mandatów i grzywien jako narzędzia polityki karnej, polityki dochodowej samorządów oraz narzędzia zdobywania poparcia politycznego.

Najszerszy nurt w literaturze dotyczącej mandatów i grzywien opisuje skuteczność tego rodzaju kar jako środka zapobiegającego wypadkom oraz zwiększającego bezpieczeństwo ruchu drogowego. Istniejące prace potwierdzaja, że zwiększenie częstotliwości kontroli drogowych oraz liczby fotoradarów zmniejsza ilość wypadków i liczbę ich ofiar². Dowiedziono również, że zwiększanie budżetów policji prowadzi do ograniczenia przestępczości, ponadto wykazano istnienie politycznego cyklu koniunkturalnego przy zwiększaniu budżetów policji i innych służb odpowiedzialnych za bezpieczeństwo publiczne ${ }^{3}$. Głównym motywem zwiększania wydatków na bezpieczeństwo niedługo przed wyborami jest chęć zdobycia dodatkowych głosów w wyborach.

Chęć zdobycia poparcia w wyborach i zwiększenia szans na reelekcję motywuje nie tylko do zwiększania wydatków na bezpieczeństwo, lecz również do zmniejszania liczby wystawianych mandatów. Lokalny polityczny cykl koniunkturalny od dziesięcioleci jest przedmiotem badań ${ }^{4}$. Dowiedziono istnienia lokalnego politycznego cyklu koniunkturalnego w dochodach z mandatów we włoskich samorządach w latach $1998-2015^{5}$. Znacznie mniejsza

\footnotetext{
2 Tay (2010): 247-257.

${ }^{3}$ Por. np. Zhao et al. (2010): 266-275 lub Guillamon, Bastida (2013): 447-469.

${ }^{4}$ Por. np. Rosenberg (1990): 71-81 lub Veiga, Veiga (2007): 45-64.

${ }^{5}$ Bracco (2018): 117-120.
} 
była liczba mandatów wystawianych w latach wyborczych oraz w samorządach rządzonych przez burmistrzów cieszących się stosunkowo niewielkim poparciem. Najbardziej prawdopodobnym wyjaśnieniem jest wpływ walczących o reelekcję polityków na organy administracyjne, by te nie nakładały dużej liczby mandatów, ponieważ z reguły irytuje to wyborców i zmniejsza szanse na reelekcję.

Obok aspektów politycznych wystawiania mandatów i nakładania grzywien przedmiotem badań był również wpływ możliwości nakładania przez samorządy tego rodzaju kar na sytuację budżetową samorządów. Udowodniono, że choć teoretycznie liczba wystawionych mandatów powinna być uzależniona wyłącznie od czynników demograficznych oraz prawnych, amerykańskie samorządy w Karolinie Północnej traktują mandaty jako niepodatkowe źródło dochodów i uzupełnienie budżetu. Presja budżetowa motywowała do zmiany sposobu egzekwowania prawa: spadek dochodów lokalnych o $1 \%$ powodował wzrost dochodów z mandatów o $0,38 \%{ }^{6}$. Ponadto liczba i ściagalność mandatów były zależne od przestrzeni fiskalnej i sytuacji budżetowej samorządu. Dziesięcioprocentowy spadek dochodów prowadził do zwiększenia liczby mandatów średnio o $6,4 \%{ }^{7}$. Wpływ sytuacji budżetowej na liczbę i dochody z mandatów udowodniono w innych pracach, wykazano również zależność między dużą liczbą mandatów a gorszym ratingiem danego samorządu ${ }^{8}$. Pokusa generowania dodatkowych dochodów niepodatkowych dotyczy nie tylko mandatów, umożliwienie konfiskat mienia przestępców na rzecz samorządów prowadziło bowiem do wielu nadużyć i zabierania mienia niezgodnie z prawem ${ }^{9}$.

W literaturze przedmiotu obecny jest również nurt badający kwestię dyskryminacji przy wystawianiu mandatów. Udowodniono, że struktura mandatów wystawionych przez fotoradary i komputery znacząco różni się od struktury mandatów wystawianych przez policję i inne służby. W przypadku komputerów nie stwierdzono dyskryminacji, natomiast policja w Stanach Zjednoczonych dużo częściej niż komputery wystawiała mandaty osobom czarnoskórym, kobietom oraz osobom zamieszkujacym odległe stany ${ }^{10}$. Również w przypadku miast położonych w Kalifornii największe wpływy z mandatów notowane sa w regionach z największym odsetkiem mniejszości etnicznych, ponadto czynniki opisujące sytuację budżetową oraz poziom rozwoju danego regionu sa nieistotne ${ }^{11}$.

W przypadku polskich samorządów literatura naukowa na temat mandatów i grzywien jest stosunkowo uboga. Dochody z mandatów i grzywien są klasyfikowane jako część stabilnych dochodów własnych, a możliwość ich

\footnotetext{
${ }^{6}$ Garett, Wagner (2006)

7 Garett, Wagner (2009): 71-90.

${ }^{8}$ Hummel (2015): 298-319.

9 Baicker, Jacobson (2007): 2113-2136.

${ }_{10}$ Makovsky, Stratman (2009): 509-527 oraz Quintanar (2017): 1-28.

11 Singla et al. (2019): 1-36.
} 
nakładania stanowi część potencjału dochodowego gminy ${ }^{12}$. W skali całego kraju stanowią one bardzo niewielką część dochodów budżetowych samorządów ${ }^{13}$.

Istniejąca luka badawcza w postaci braku ilościowego badania dochodów z mandatów i grzywien polskich samorządów stanowi motywację do jego przeprowadzenia. Z literatury przedmiotu wynika, że musi ono uwzględniać trzy czynniki: przestępczość i bezpieczeństwo ruchu drogowego, sytuację budżetową samorządów oraz czynniki polityczne wpływające na wystawianie mandatów.

\section{DOCHODY Z MANDATÓW I GRZYWIEN W POLSKICH GMINACH W LATACH 2007-2017}

Badanie wysokości, zmienności i struktury dochodów polskich gmin z mandatów i grzywien wymaga analizy dużej ilości danych. Wykorzystano sprawozdania budżetowe jednostek samorządu terytorialnego publikowane przez Ministerstwo Finansów w formie zbiorczej bazy Rb27s (sprawozdań z wykonania planu dochodów) w latach 2007-2017. Istniejąca klasyfikacja budżetowa pozwoliła na wyodrębnienie dochodów z mandatów i grzywien (paragrafy 057 i 058) we wszystkich działach klasyfikacji budżetowych wszystkich gmin i miast na prawach powiatu w Polsce. Wykorzystano również dane o wydatkach na straż miejską lub gminną (rozdział 75 416), dane o wydatkach inwestycyjnych na bezpieczeństwo publiczne (paragrafy 605 i $606 \mathrm{w}$ dziale 754), dane o wydatkach na obsługę długu (dział 757) oraz dochodach i wydatkach ogółem. Ze względu na zróżnicowanie gmin pod względem liczby ludności w badaniu wykorzystano wielkości w przeliczeniu na mieszkańca (per capita).

Suma dochodów z mandatów i grzywien gmin ulegała znacznym zmianom w czasie. Między 2007 a 2013 zanotowano czterokrotny wzrost dochodów $\mathrm{z}$ mandatów. Były to dochody spodziewane, znacznie bowiem wzrosły również wartości planowanych dochodów z mandatów zapisane w uchwałach budżetowych. W tym okresie nie odnotowano znaczących zmian legislacyjnych ani gwałtownego wzrostu liczby wykroczeń. Najbardziej prawdopodobną hipoteza wyjaśniająca gwałtowny wzrost dochodów z mandatów i grzywien w latach 2007-2013 oraz ich spadek w kolejnych latach jest zmiana deficytu podsektora samorządowego. Występuje silna korelacja między deficytem podsektora samorządowego w Polsce a dochodami samorządów z mandatów i grzywien (wykres 1).

\footnotetext{
12 Filipiak (2016): 643-653.

${ }^{13}$ Felis (2010): 91-114.
} 


\section{Wykres 1}

Suma dochodów samorządów wykonanych i planowanych z tytułu mandatów i grzywien oraz deficyt podsektora samorządowego w latach 2007-2018 ${ }^{14}$

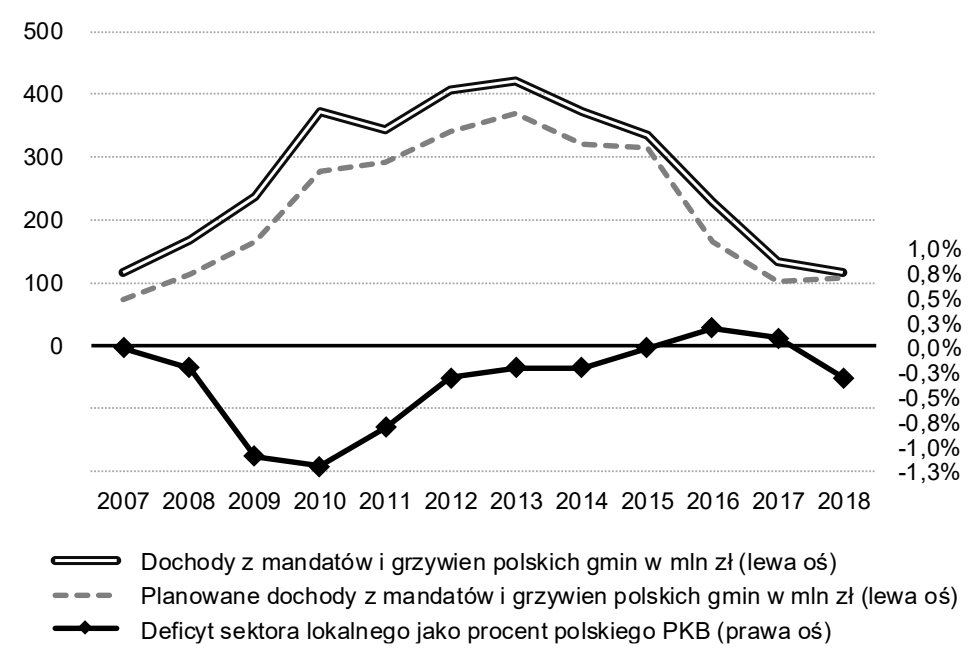

Źródło: obliczenia własne na podstawie danych Eurostatu i Ministerstwa Finansów.

Wysokie tempo wzrostu dochodów z mandatów i grzywien odnotowano w skali całej Polski, wzrosty te jednak nie były jednakowe we wszystkich gminach. Średnia roczna wartość dochodów gmin z mandatów i grzywien w przeliczeniu na mieszkańca wynosiła 5,57 zł w latach 2007-2017, jednakże rozkład średnich dochodów w przeliczeniu na mieszkańca ukazuje duże zróżnicowanie gmin. W badaniu uwzględniono 2474 gminy spośród 2478 gmin w Polsce (cztery gminy wykluczono ze względu na ich likwidację, wchłonięcie do innej gminy lub podział). Spośród nich 2126 gmin odnotowało dochody z mandatów i grzywien per capita na poziomie poniżej ogólnopolskiej średniej, natomiast 348 gmin - powyżej średniej. Ponad 40 gmin w Polsce odnotowało dochody z mandatów i grzywien na poziomie dziesięciokrotnie wyższym niż ogólnopolska średnia, 19 gmin - na poziomie ponaddwudziestokrotnie wyższym niż ogólnopolska średnia, a średnie roczne dochody z mandatów i grzywien per capita gminy rekordzistki Biały Bór wyniosły 694,11 zł i przewyższały ogólnopolska średnią ponad 124-krotnie. Na wykresie 2 zaprezentowano rozkład średnich rocznych dochodów gmin z mandatów i grzywien w przeliczeniu na mieszkańca.

${ }^{14} \mathrm{~W}$ momencie ukończenia artykułu dane za 2018 r. dostępne były jedynie w ujęciu zagregowanym (dla wszystkich gmin w Polsce). 
Wykres 2

Rozkład średnich rocznych dochodów gmin z mandatów w przeliczeniu na mieszkańca (siedem obserwacji znajduje się poza skala)

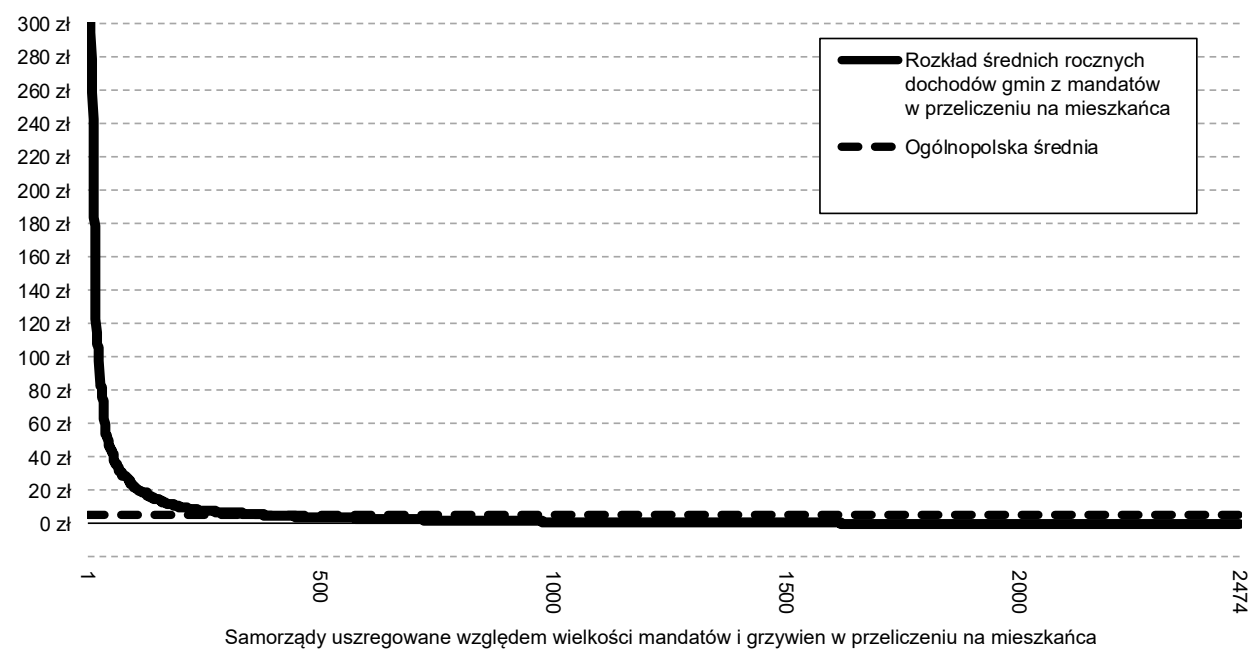

Źródło: obliczenia własne na podstawie danych GUS i Ministerstwa Finansów.

Tak duża liczba obserwacji znacząco odbiegajacych od średniej rodzi pytanie o przyczynę tak dużego zróżnicowania dochodów z mandatów i grzywien. Na potrzeby badania podzielono gminy na cztery grupy w zależności od średnich dochodów per capita z mandatów i grzywien. W polskich gminach $78,1 \%$ dochodów z mandatów i grzywien rejestrowanych jest w trzech działach: Transport i łączność (600), Bezpieczeństwo publiczne i ochrona przeciwpożarowa (754) oraz Gospodarka komunalna (900). W tabeli 1 znajdują się informacje na temat dochodów z mandatów i grzywien 12 gmin, które odnotowały najwyższe średnie dochody z mandatów per capita w latach 2007-2017. W 11 gminach spośród 12 ponad 99\% dochodów z mandatów i grzywien odnotowano w rozdziale 75416 straż miejska lub gminna. Mandaty wystawiane przez straż miejską lub gminną stanowiły od $6,11 \%$ do $15,20 \%$ dochodów ogółem tych gmin. Tak duży udział dochodów z mandatów i grzywien w dochodach ogółem pozwala stwierdzić, że mandaty i grzywny stały się jednym z głównych źródeł finansowania tych samorządów.

Można zaobserwować duże zróżnicowanie geograficzne gmin o dochodach z mandatów i grzywien per capita dziesięciokrotnie przekraczających ogólnopolską średnią. Na mapie 1 zaznaczono gminy, które przekraczają ogólnopolska średnia pod względem dochodów z mandatów. Część z tych gmin jest położona w województwach o PKB per capita powyżej ogólnopolskiej średniej (pomorskie, wielkopolskie, mazowieckie, dolnoślaskie), pozostałe w województwach o PKB per capita poniżej ogólnopolskiej średniej. Część jest położona w regionach o niskiej gęstości zaludnienia, część w regionach o wysokiej gęstości zaludnienia. Dominuja gminy wiejskie, lecz wśród gmin o wysokich dochodach z manda- 
tów pojawiają się również gminy miejskie i jedno miasto na prawach powiatu (Sopot). Na terenie większości gmin nie ma autostrad ani dróg ekspresowych, a w kilku przypadkach nie ma dróg krajowych, więc wysokie mandaty nie wynikają z położenia przy drogach o dużym ruchu samochodowym.

Tabela 1

Średnie roczne dochody per capita gmin z mandatów i grzywien - dwanaście gmin o najwyższych dochodach i ogólnopolska średnia

\begin{tabular}{|c|c|c|c|c|c|c|c|}
\hline $\begin{array}{l}\text { Nazwa } \\
\text { gminy }\end{array}$ & $\begin{array}{l}\text { Typ } \\
\text { gminy }\end{array}$ & $\begin{array}{l}\text { Woje- } \\
\text { wódz- } \\
\text { two }\end{array}$ & $\begin{array}{c}\text { Mandaty } \\
\text { i grzywny } \\
\text { w dziale } \\
\text { Trans- } \\
\text { port } \\
\text { i łączność } \\
(600)\end{array}$ & $\begin{array}{c}\text { Mandaty } \\
\text { i grzywny } \\
\text { w dziale } \\
\text { Bezpie- } \\
\text { czeństwo } \\
\text { publicz- } \\
\text { ne (754) }\end{array}$ & $\begin{array}{c}\text { Mandaty } \\
\text { i grzywny } \\
\text { w dziale } \\
\text { Gospo- } \\
\text { darka } \\
\text { komunal- } \\
\text { na (900) }\end{array}$ & $\begin{array}{c}\text { Mandaty } \\
\text { i grzywny } \\
\text { w prze- } \\
\text { liczeniu } \\
\text { na miesz- } \\
\text { kańca }\end{array}$ & $\begin{array}{l}\text { Mandaty } \\
\text { jako pro- } \\
\text { cent do- } \\
\text { chodów } \\
\text { ogółem }\end{array}$ \\
\hline Biały Bór & $\begin{array}{l}\text { miejsko- } \\
\text {-wiejska }\end{array}$ & $\begin{array}{l}\text { zachod- } \\
\text { niopo- } \\
\text { morskie }\end{array}$ & $0,55 \mathrm{zł}$ & $689,81 \mathrm{zł}$ & $0,05 \mathrm{zł}$ & $694,11 \mathrm{zł}$ & $15,20 \%$ \\
\hline Kęsowo & wiejska & $\begin{array}{l}\text { kujaw- } \\
\text { sko-po- } \\
\text { morskie }\end{array}$ & $0,00 \mathrm{zł}$ & $594,09 \mathrm{zl}$ & $0,00 \mathrm{zł}$ & $615,28 \mathrm{zl}$ & $14,50 \%$ \\
\hline Człuchów & wiejska & $\begin{array}{l}\text { pomor- } \\
\text { skie }\end{array}$ & $0,08 \mathrm{zl}$ & $419,49 \mathrm{zl}$ & $0,06 \mathrm{zl}$ & $424,93 \mathrm{zl}$ & $10,41 \%$ \\
\hline Rzeczenica & wiejska & $\begin{array}{l}\text { pomor- } \\
\text { skie }\end{array}$ & $0,00 \mathrm{zł}$ & $407,66 \mathrm{zl}$ & $0,25 \mathrm{zl}$ & $407,92 \mathrm{zł}$ & $9,97 \%$ \\
\hline Powidz & wiejska & $\begin{array}{l}\text { wielko- } \\
\text { polskie }\end{array}$ & $0,00 \mathrm{zł}$ & $0,00 \mathrm{zł}$ & $371,05 \mathrm{zl}$ & $371,47 \mathrm{zł}$ & $7,30 \%$ \\
\hline $\begin{array}{l}\text { Kamienica } \\
\text { Polska }\end{array}$ & wiejska & śląskie & $0,04 \mathrm{zł}$ & $329,44 \mathrm{zl}$ & $0,00 \mathrm{zl}$ & $329,48 \mathrm{zł}$ & $11,36 \%$ \\
\hline Kobylnica & wiejska & $\begin{array}{l}\text { pomor- } \\
\text { skie }\end{array}$ & $1,69 \mathrm{zł}$ & $293,03 \mathrm{zł}$ & $0,00 \mathrm{zl}$ & $294,72 \mathrm{zl}$ & $6,60 \%$ \\
\hline Karlino & $\begin{array}{l}\text { miejsko- } \\
\text {-wiejska }\end{array}$ & $\begin{array}{l}\text { zachod- } \\
\text { niopo- } \\
\text { morskie }\end{array}$ & $0,40 \mathrm{zl}$ & $274,90 \mathrm{zl}$ & $0,97 \mathrm{zl}$ & $279,10 \mathrm{zl}$ & $5,88 \%$ \\
\hline $\begin{array}{l}\text { Nowe } \\
\text { Ostrowy }\end{array}$ & wiejska & łódzkie & $0,00 \mathrm{zl}$ & $272,37 \mathrm{zł}$ & $0,00 \mathrm{zł}$ & $272,37 \mathrm{zł}$ & $7,35 \%$ \\
\hline Tarczyn & $\begin{array}{l}\text { miejsko- } \\
\text {-wiejska }\end{array}$ & $\begin{array}{l}\text { mazo- } \\
\text { wieckie }\end{array}$ & $0,00 \mathrm{zl}$ & $254,57 \mathrm{zl}$ & $0,97 \mathrm{zł}$ & $258,59 \mathrm{zł}$ & $7,22 \%$ \\
\hline Debrzno & $\begin{array}{l}\text { miejsko- } \\
\text {-wiejska }\end{array}$ & $\begin{array}{l}\text { pomor- } \\
\text { skie }\end{array}$ & $0,00 \mathrm{zl}$ & $243,23 \mathrm{zł}$ & $0,00 \mathrm{zł}$ & $243,23 \mathrm{zł}$ & $6,39 \%$ \\
\hline Trzebielino & wiejska & $\begin{array}{l}\text { pomor- } \\
\text { skie }\end{array}$ & $0,00 \mathrm{zł}$ & $228,41 \mathrm{zł}$ & $0,29 \mathrm{zł}$ & $228,70 \mathrm{zł}$ & $6,11 \%$ \\
\hline $\begin{array}{l}\text { POLSKA } \\
\text { (średnia) }\end{array}$ & - & - & $0,27 \mathrm{zl}$ & $3,76 \mathrm{zl}$ & $0,53 \mathrm{zl}$ & $5,57 \mathrm{zl}$ & $0,15 \%$ \\
\hline
\end{tabular}

Źródło: obliczenia własne na podstawie danych GUS i Ministerstwa Finansów. 


\section{Mapa 1}

Dochody gmin z mandatów i grzywien per capita w porównaniu z ogólnopolską średnią dochodów gmin z mandatów i grzywien per capita

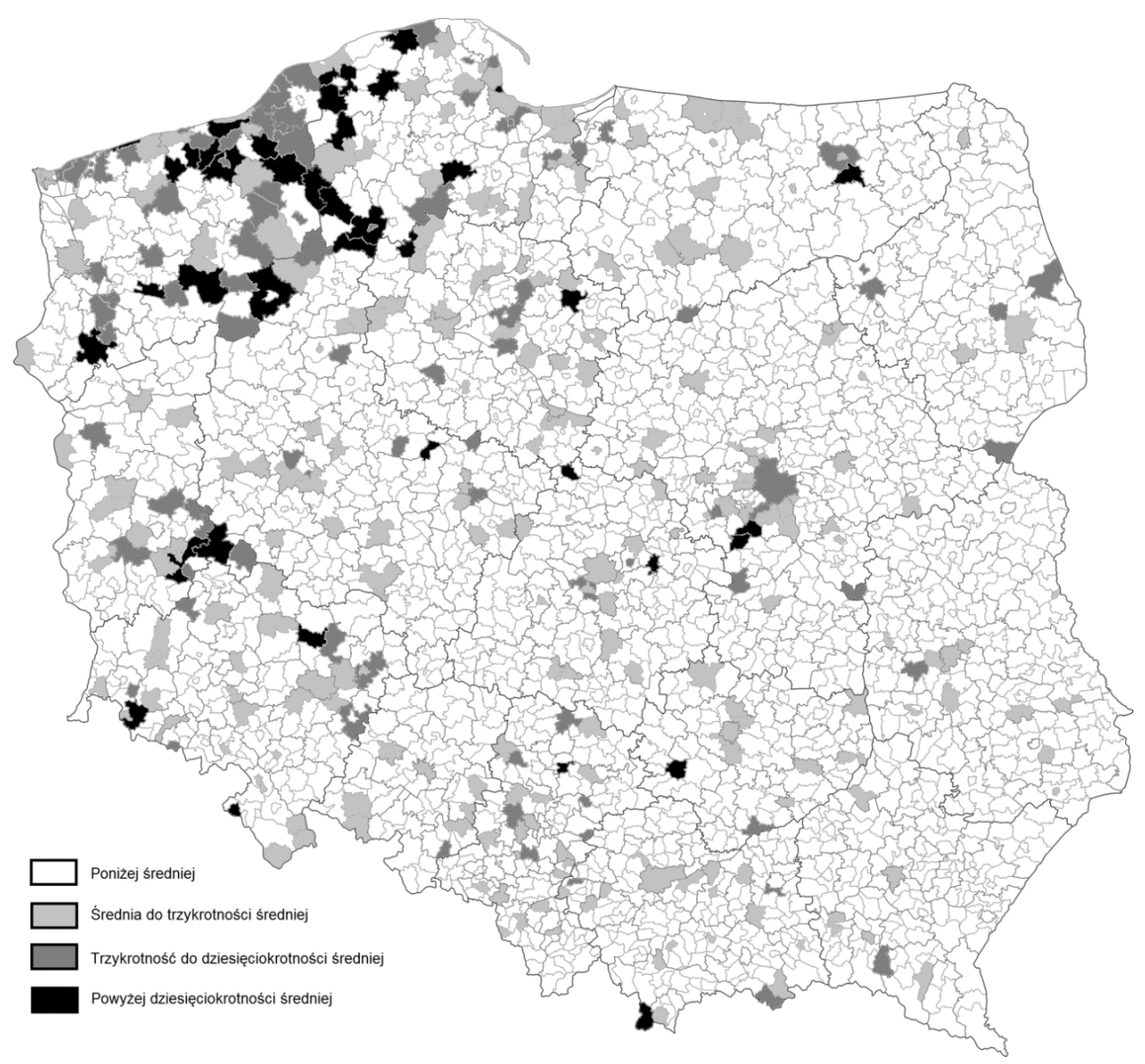

Źródło: obliczenia własne na podstawie danych GUS i Ministerstwa Finansów. Wykorzystano mapę konturową udostępnioną na licencji Wikimedia Commons (wolny dostęp), <https://commons.wikimedia. org/wiki/File:POLSKA_woj_pow_gminy_2013.png>.

Trudno zaobserwować jeden czynnik geograficzny lub ekonomiczny różnicujący te gminy. Przykładowo w Gdyni i Gdańsku poziom mandatów niewiele przekracza ogólnopolska średnią (odpowiednio 6,03 zł i 7,84 zł), natomiast w Sopocie dochody z mandatów są dużo wyższe (82,82 zł). Podobnie w Słupsku - we wszystkich gminach graniczacych ze Słupskim poziom mandatów ponaddziesięciokrotnie przekracza średnia, natomiast w samym Słupsku dochody z mandatów per capita są niższe od ogólnopolskiej średniej. Na Podhalu gmina Krościenko odnotowała średnie dochody z mandatów na poziomie 81,35 zł, natomiast sasiednie gminy Zakopane i Poronin na poziomie, odpowiednio, 5,17 zł i 2,01 zł. Jedyną zaobserwowaną prawidłowością jest fakt, że 23 spośród 40 gmin 
o najwyższych mandatach leżą na terenie województw pomorskiego i zachodniopomorskiego. Można jednak domniemywać, że duża koncentracja takich gmin wynika z dyfuzji wiedzy - politycy rządzący jedna gminą obserwują zachowania polityków rządzących gminami w tym samym regionie i wdrażają te same rozwiązania u siebie. W województwach pomorskim i zachodniopomorskim gminy o najwyższych dochodach z mandatów sassiadują z gminami o wyjątkowo niskich dochodach z mandatów.

Wszystko to pozwala sądzić, że dochody z mandatów i grzywien w gminach znacząco przekraczających średnią nie są wynikiem wysokiej przestępczości, poziomu rozwoju gospodarczego regionu ani położenia przy ruchliwej drodze. Wysokie dochody z mandatów per capita w większości gmin są skutkiem uznaniowej decyzji władz gminy o powołaniu straży miejskiej i zobowiązaniu jej do wystawiania wysokich mandatów.

\section{DANE I MODEL}

Choć obserwacje i dane statystyczne wskazują na wykorzystywanie mandatów i grzywien do generowania dodatkowych dochodów budżetowych, potrzebna jest weryfikacja empiryczna. Z przeglądu literatury i teorii ekonomii wynika, że mandaty i grzywny mogą być częścią polityki karnej, polityki budżetowej i narzędziem zdobywania poparcia w wyborach. Z tego względu stworzono model ekonometryczny, którego celem jest weryfikacja hipotez o wpływie tych czynników na wysokość mandatów w polskich gminach. Weryfikacja hipotez o istotności i odpowiednim znaku zmiennych fiskalnych, zmiennych opisujących poziom przestępczości oraz cykl wyborczy w modelu panelowym pozwala na wnioskowanie o roli polityki budżetowej, polityki karnej i cyklu politycznego w kształtowaniu dochodów z mandatów i grzywien w polskich gminach.

W modelu wykorzystano dane panelowe z 2474 gmin w Polsce z lat 20072017. Uwzględniono 6 różnych zmiennych, uwzględniajacych przestępczość, sytuację budżetową gminy oraz możliwy cykl polityczny. Zmienną objaśniana w modelu sa dochody z mandatów i grzywien w przeliczeniu na mieszkańca $\mathrm{w}$ danym samorządzie $\mathrm{w}$ danym roku. W celu zbadania odporności modelu (ang. robustness checks) dokonano 3 kolejnych estymacji z tymi samymi zmiennymi objaśniającymi, w których zmiennymi objaśnianymi są dochody z mandatów w trzech działach budżetowych: Transport i łacczność (600), Bezpieczeństwo publiczne i ochrona przeciwpożarowa (754) oraz Gospodarka komunalna (900).

Zmienną mająca na celu zweryfikowanie hipotezy o istnieniu lokalnego politycznego cyklu koniunkturalnego jest zmienna „Cykl wyborczy”. Przyjmuje ona wartość 3 na 3 lata przed wyborami samorządowymi (tj. 2007, 2011, 2015), wartość 2 na 2 lata przed wyborami (tj. 2008, 2012, 2016) itd. Istotność i dodatni znak zmiennej byłby podstawą do zweryfikowania hipotezy o celowym zmniejszaniu liczby mandatów przed wyborami. 
Zmienną uwzględniającą liczbę wykroczeń i przestępstw drogowych jest zmienna „Przestępczość”. Z powodu braku lepszych danych włączono do niej liczbę kierowców skazanych za prowadzenie pojazdu w stanie nietrzeźwości w przeliczeniu na jednego mieszkańca regionu. Źródłem danych o skazanych nietrzeźwych kierowcach są statystyki publikowane przez polską policję.

Do modelu włączono również zmienne oddające sytuację budżetowa, takie jak koszt obsługi długu per capita oraz deficyt pierwotny per capita (tj. deficyt nominalny per capita po odjęciu kosztów obsługi długu per capita). Wysoki deficyt i wysokie zadłużenie może być przyczyną powstawania presji na zwiększanie dochodów gminy i zwiększanie dochodów z mandatów. Włączenie do modelu deficytu pierwotnego zamiast deficytu nominalnego wynika $\mathrm{z}$ faktu, że deficyt pierwotny jest $\mathrm{z}$ definicji mniej skorelowany z kosztami obsługi długu niż deficyt nominalny. Uwzględnienie w modelu dwóch zmiennych fiskalnych wynika $\mathrm{z}$ faktu, że deficyt pierwotny jest miara poziomu krótkookresowej stabilności finansów samorządu, natomiast koszty obsługi długu per capita sa miara długookresowej stabilności finansów samorządu. Dodatkowo w modelu uwzględniono wydatki per capita na straż miejską lub gminną oraz wydatki per capita na inwestycje w dziale budżetowym Bezpieczeństwo publiczne i ochrona przeciwpożarowa (754).

Model oszacowano za pomoca dwukierunkowego modelu panelowego z efektami stałymi (ang. two-way Fixed Effects). Wyniki estymacji znajduja się w tabeli 2 .

Tabela 2

Wyniki estymacji modeli

\begin{tabular}{|l|c|c|c|c|}
\hline \multirow{2}{*}{$\begin{array}{c}\text { Zmienne } \\
\text { objaśniające }\end{array}$} & $\begin{array}{c}\text { Dochody } \\
\text { z mandatów } \\
\text { i grzywien } \\
\text { per capita }\end{array}$ & $\begin{array}{c}\text { Dochody } \\
\text { z mandatów } \\
\text { i grzywien } \\
\text { per capita } \\
\text { w dziale } 600\end{array}$ & $\begin{array}{c}\text { Dochody } \\
\text { z mandatów } \\
\text { i grzywien } \\
\text { per capita } \\
\text { w dziale } 754\end{array}$ & $\begin{array}{c}\text { Dochody } \\
\text { z mandatów } \\
\text { i grzywien } \\
\text { per capita } \\
\text { w dziale } 900\end{array}$ \\
\hline $\begin{array}{l}\text { Koszt obsługi } \\
\text { długu per capita }\end{array}$ & $-0,0097$ & 0,0001 & $-0,0053$ & 0,0025 \\
\cline { 2 - 5 } & $(0,0077)$ & $(0,0014)$ & $(0,0101)$ & $(0,002)$ \\
\hline $\begin{array}{l}\text { Deficyt } \\
\text { pierwotny } \\
\text { per capita }\end{array}$ & 0,0002 & 0,0000 & 0,0003 & 0,0004 \\
\hline $\begin{array}{l}\text { Wydatki na } \\
\text { straż miejską } \\
\text { (gminna) } \\
\text { per capita }\end{array}$ & $(0,1195)$ & $(0,0000)$ & $(0,0003)$ & $(0,0004)$ \\
\cline { 2 - 5 } & $1,7541^{* * *}$ & $-0,0022$ & $1,7609 * * *$ & 0,0006 \\
\hline $\begin{array}{l}\text { Inwestycje } \\
\text { w dziale 754 } \\
\text { per capita }\end{array}$ & $(0,1195)$ & $(0,0027)$ & $(0,1227)$ & $(0,002)$ \\
\cline { 2 - 5 } & $(0,006)$ & $(0,0004)$ & $(0,0058)$ & $(0,0007)$ \\
\hline
\end{tabular}




\begin{tabular}{|l|c|c|c|c|}
\hline $\begin{array}{l}\text { Liczba } \\
\text { nietrzeźwych } \\
\text { kierowców } \\
\text { per capita }\end{array}$ & $1537,191^{* * *}$ & 8,312 & $1350,485^{* * *}$ & $-58,6438$ \\
\cline { 2 - 5 } & $(528,8312)$ & $(46,8495)$ & $(490,3775)$ & $(96,5724)$ \\
\hline \multirow{2}{*}{ Cykl wyborczy } & $-0,7667 * *$ & $-0,1097 * * *$ & 0,0122 & $-0,4001$ \\
\cline { 2 - 5 } & $(0,3322)$ & $(0,0417)$ & $(0,1724)$ & $(0,2746)$ \\
\hline \multirow{2}{*}{\begin{tabular}{l} 
Stała \\
\cline { 2 - 5 }
\end{tabular}} & $(2,5486)$ & $(0,1611)$ & $(2,2687)$ & $(0,9148)$ \\
\hline Efekty czasowe & Uwzględniono & Uwzględniono & Uwzględniono & Uwzględniono \\
\hline Test Walda & $39,00 * * *$ & $4,20 * * *$ & $35,61 * * *$ & $4,95 * * *$ \\
\hline $\begin{array}{l}R \text {-kwadrat } \\
\text { całkowity }\end{array}$ & 0,5757 & 0,0007 & 0,6215 & 0,0009 \\
\hline Liczba gmin & 2474 & 2474 & 2474 & 2474 \\
\hline Liczba okresów & 11 & 11 & 11 & 11 \\
\hline $\begin{array}{l}\text { Liczba } \\
\text { obserwacji }\end{array}$ & 27214 & 27214 & 27214 & 27214 \\
\hline
\end{tabular}

Błędy standardowe znajdują się w nawiasach. Wartość $p$ testu istotności zmiennej w modelu oznaczono asteryskami $(*, * * * * *$ oznacza wartość $p$ mniejszą od 0,$1 ; 0,05 ; 0,01$ odpowiednio)

Źródło: obliczenia własne na podstawie danych GUS, Policji i Ministerstwa Finansów.

\section{WYNIKI ESTYMACJI MODELU}

Oszacowane wartości parametrów, wyniki testów statystycznych oraz wysokie $R$-kwadrat modelu wskazują na właściwy dobór zmiennych objaśniajacych. Istotność zmiennych oraz znak oszacowanych parametrów pozawala na oszacowanie wpływu poziomu przestępczości, sytuacji budżetowej gmin oraz cyklu politycznego na dochody z mandatów.

Zmienna opisująca względną liczbą nietrzeźwych kierowców w regionie jest istotna, a wartość parametru jest wysoka i dodatnia. Potwierdza to fakt powiązania dochodów samorządów z mandatów i grzywien z liczbą przestępstw na drogach. Podstawowym celem wystawiania mandatów i nakładania grzywien jest prewencja ogólna i szczególna. Świadczy to o tym, że w pewnym stopniu mandaty faktycznie służa jako środek polityki karnej państwa. Pozwala to na pozytywne zweryfikowanie hipotezy o wpływie poziomu przestępczości na wysokość dochodów z mandatów i grzywien polskich gmin.

Zmienne oddające sytuację budżetowa gminy pozostaja nieistotne we wszystkich przypadkach, co wskazuje na brak wyraźnego powiązania długu i deficytu gminy z dochodami z mandatów i grzywien. Z kolei zmienna opisująca cykl polityczny jest istotna statystycznie, lecz ujemna. Przeczy to hipotezie o zmniejszaniu ilości wystawianych mandatów przed wyborami samorządowymi i świadczy o istnieniu zjawiska wręcz przeciwnego - dochody per capita samorządów z mandatów i grzywien są wyższe na krótko przed wy- 
borami. Jest to dowód pewnej odpowiedzialności ze strony polityków samorządowych w zakresie zarządzania budżetem gminy i dowód funkcjonowania dobrych instytucji politycznych. Hipotezę o istnieniu lokalnego politycznego cyklu koniunkturalnego $\mathrm{w}$ dochodach z mandatów i grzywien należy uznać za nieprawdziwa.

Znaczny wpływ na dochody z mandatów mają wydatki na straż miejską (gminna). Wartość parametru równania jest istotna statystycznie i istotnie wyższa od 1. Oznacza to, że wydatki na tę formację „zwracają się" z nawiązka (po uwzględnieniu oddziaływania innych zmiennych), a stworzenie straży miejskiej (gminnej) jest dla samorządów opłacalne i pozwala na znaczne zwiększenie dochodów budżetowych. Rodzi to pytanie o rzeczywisty cel powoływania tych instytucji. Głównym powodem powoływania straży miejskiej (gminnej) powinna być dbałość o porządek i bezpieczeństwo publiczne, natomiast wyniki wskazują na dużą rolę tych służb w generowaniu dochodów $\mathrm{z}$ mandatów.

Choć zmienne fiskalne są nieistotne statystycznie, ścisła zależność dochodów gmin z mandatów i grzywien od wydatków na straż miejską (gminna) dowodzi, że mandaty i grzywny sa w pewnym stopniu instrumentem polityki budżetowej gmin. $\mathrm{Z}$ tego względu decyzję o powołaniu straży miejskiej (gminnej) należy rozpatrywać jako decyzję wpływająca na wielkość wydatków, ale również na potencjalną wielkość dochodów niepodatkowych. Analiza finansów gmin z bardzo wysokimi wpływami z mandatów i grzywien również potwierdza fakt stosowania mandatów i grzywien jako instrumentów polityki budżetowej.

W celu sprawdzenia odporności wyników dokonano oszacowań trzech kolejnych równań, w których zmienną objaśniana sa dochody z mandatów w poszczególnych działach klasyfikacji budżetowej. W przypadku dochodów z mandatów w działach Transport i łączność (600) oraz Gospodarka komunalna (900) trudno wyciagnąć jakiekolwiek wnioski ze względu na nieistotność zmiennych, wysokie błędy standardowe i bardzo niską wartość $R$-kwadrat. Z kolei w dziale Bezpieczeństwo publiczne i ochrona przeciwpożarowa (754) wyniki oszacowania modelu są bardzo podobne do wyników oszacowania głównego równania modelu. W tym dziale uwzględniane są dochody z mandatów wystawionych przez straż miejską (gminna) i ponownie potwierdzona jest jej duża rola w generowaniu dochodów niepodatkowych.

\section{WNIOSKI}

Artykuł przedstawia dogłębną analizę zróżnicowania dochodów samorządów terytorialnych z mandatów i grzywien. Kary finansowe z zasady powinny być wyłącznie środkiem polityki karnej, a celem ich wystawiania powinno być zapobieganie przestępstwom i wykroczeniom. Mimo to mandaty mogą być wykorzystywane do generowania dodatkowych dochodów budżetowych oraz wpływać na poparcie polityków w wyborach, dlatego dokonano weryfikacji hi- 
potez o wpływie poszczególnych czynników na dochody budżetowe 2474 polskich gmin w latach 2007-2017.

Analiza statystyczna i obserwacje wskazują na duże zróżnicowanie dochodów z mandatów per capita samorządów terytorialnych w Polsce. Istnieje grupa gmin, w których dochody z mandatów per capita są wielokrotnie wyższe od ogólnopolskiej średniej. Dochody generowane są głównie przez mandaty wystawiane przez straż miejską (gminna). Odnalezienie jednego czynnika różnicującego te gminy jest trudne. Wyniki badania wskazuja, że głównym powodem wysokich dochodów z mandatów jest decyzja polityczna o utworzeniu straży miejskiej (gminnej) i nałożeniu na nią obowiązku wystawiania dużej liczby mandatów. Dane potwierdzaja, że inwestycja w nią,zwraca się” w zdecydowanej większości przypadków, tzn. dochody samorządów z mandatów sa wyższe niż wydatki na utrzymanie tych instytucji.

W celu weryfikacji hipotez stworzono model ekonometryczny. Wyniki pozwalają stwierdzić, że zmienne opisujące sytuację budżetową są nieistotne statystycznie. Oszacowania parametrów i wyniki testów przeczą hipotezie o nakładaniu mniejszej liczby mandatów przed wyborami samorządowymi w celu zdobycia poparcia. Głównym źródłem dochodów samorządów z mandatów jest funkcjonowanie straży miejskiej (gminnej).

\section{Eukasz Wiktor Olejnik}

Szkoła Gtówna Handlowa w Warszawie

lo56801@doktorant.sgh.waw.pl

https://orcid.org/0000-0002-4250-961X

Baicker, K., Jacobson, M. (2007). Finders keepers: forfeiture laws, policing incentives, and local budgets. Journal of Public Economics 91(11/12): 2113-2136.

Bracco, E. (2018). A fine collection: the political budget cycle of traffic enforcement. Economics Letters 164(1): 117-120.

Felis, P. (2010). Główne źródła dochodów budżetowych w Polsce. Studia BAS 23(3): 91-114.

Filipiak, B. (2016). Podatkowe czynniki kształtujące potencjał finansowy jednostek samorządu terytorialnego. Finanse, Rynki Finansowe, Ubezpieczenia 79(1): 643-653.

Garett, T., Wagner, G. (2006). Are traffic tickets countercyclical? SSRN Electronic Journal 48A.

Garett T., Wagner, G. (2009). Red ink in the rearview mirror: local fiscal conditions and the issuance of traffic tickets. The Journal of Law and Economics 52(1): 71-90.

Guillamon, D., Bastida, F. (2013). The electoral budget cycle on municipal police expenditure. European Journal of Law and Economics 36(3): 447-469.

Hummel, D. (2015). Traffic tickets: public safety concerns or budget building tools. Administration and Society 47(3): 298-319.

Makovsky, M., Stratmann, T. (2009). Political economy at any speed: what determines traffic citations. American Economic Review 99(1): 509-527.

Najwyższa Izba Kontroli (2013). Prawidłowość realizacji zadań przez Straże Miejskie (Gminne) w zakresie wykorzystania urządzeń do pomiaru i rejestracji wykroczeń drogowych. KPB4113-01-00/2013. Warszawa.

Quintanar, S. (2017). Man vs. machine: an investigation of speeding ticket disparities based on gender and race. Journal of Applied Economics 20(1): 1-28.

Rosenberg, J. (1990). Rationality and the political business cycle: the case of local government. Public Choice 73(1/2): 71-81.

Singla, A., Kirschner, C., Stone, S. (2019). Race, representation and revenue: reliance on fines and forfeitures in city governments. Urban Affairs Review 55(1): 1-36. 
Tay, R. (2010). Speed cameras - improving safety or raising revenue? Journal of Transport Economics and Policy 44(2): 247-257.

Veiga, L.G., Veiga, F.J. (2007). Political business cycles at the municipal level. Public Choice 131(1/2): 45-64.

Zhao, J., Ren L., Lovrich, N. (2010). Budgetary support for police services in U.S. municipalities: comparing political culture, socioeconomic characteristics and incrementalism as rival explanations for budget share allocation to police. Journal of Criminal Justice 38(3): 266-275.

\section{TICKETS AND FINES IN POLISH COUNTIES \\ - AN INSTRUMENT OF CRIMINAL POLICY OR BUDGETARY POLICY?}

\section{Summary}

The aim of this article is to conduct an analysis of non-tax revenue from fines and tickets in Polish local governments and to verify hypotheses covering their real causes. On the basis of a created dataset of revenues from tickets in the relevant budget divisions of 2,474 counties in Poland in the 2007-2017 period, the diversity of revenues from tickets in Polish counties was examined. Data analysis indicates that there is a group of counties in Poland where tickets and fines became the instrument of budgetary policy and a way to generate significant non-tax revenue. The results of econometric model estimation confirm a dependency between revenue from tickets and crime, the macroeconomic situation and expenditures on municipal police. A fall of revenues from tickets before local elections was not observed.

Keywords: tickets; fines; local government non-tax revenue; local political business cycle; JEL: H71, K14 